ESJ Social Sciences

\title{
Whistleblowing Attitudes of Employees During Pandemic Process: A Research in Bursa
}

Nilufer Ruzgar, Assist. Prof. Dr.

Bursa Technical University, Turkey

Doi:10.19044/esj.2021.v17n32p44

Submitted: 09 August 2021

Accepted: 10 September 2021

Published: 30 September 2021
Copyright 2021 Author(s)

Under Creative Commons BY-NC-ND

4.0 OPEN ACCESS

Cite As:

Ruzgar N. (2021). Whistleblowing Attitudes of Employees During Pandemic Process: A Research in Bursa. European Scientific Journal, ESJ, 17 (32), 44.

https://doi.org/10.19044/esj.2021.v17n32p44

\begin{abstract}
Whistleblowing is reporting the unethical events within the organization to superiors and/or external parties. When it is managed professionally, it can be helpful for the organizations in order to prevent degenerating of activities. On the other hand, if it cannot be managed professionally, whistleblowing can be harmful for the organizations in terms of causing harm to the reputation of the organizations. In this context, this paper focuses on finding out the whistleblowing attitudes of the white collar employees in the production sector. In the scope of the research, the employees in the automotive sector in Bursa city are taken as samples. A survey form that consists of demographic questions and Whistleblowing Scale is applied to the potential participants via email. 235 responses have been gathered and the data is analyzed via SPSS 22.0 package programme. According to the results, there is a statistically significant difference between the socio-demographic characteristics of the employees and their attitudes towards whistleblowing. It is concluded that the employees use whistleblowing both internally and externally.
\end{abstract}

Keywords: Whistleblowing, pandemic, production sector

\section{Introduction}

When the concept of "whistleblowing" is examined, it is observed that there is no consensus on its definition (Cemaloğlu \& Akyürek, 2017). In general terms, whistleblowing is an ethical situation in which an employee is 
aware of an unethical behavior in the organization and notifies this to the authorities in or out of the organization (Cross \& Tiller, 1998; Becker, 2014; Delk, 2013). Although whistleblowers are generally among the former employees of the organization, they may be among the current employees as well (Poitras, 2014; Baltac1 \& Balc1, 2017).

Today, rapidly changing and developing information and communication technologies significantly affect human resources management in organizations. In addition, unpredictable situations and crises such as COVID-19 pandemic affect employees, who carry different characteristics. Therefore, new management strategies are needed. Among these strategies, whistleblowing strategies should also be developed and followed professionally because of the fact that business ethics have an important place in management practices in developed societies. With the implementation of these strategies, organizational development and efficiency can be increased (Cemaloğlu \& Akyürek, 2017).

In this sense, the purpose of this research is to investigate the attitudes of employees when it comes to whistleblowing. This paper starts with the definition and examples of whistleblowing and continues with the ways of whistleblowing along with the facts that cause whistleblowing. Based on examples from previous research, the statistical research is presented in the methodology section. In the scope of the research, white collar employees (who work mentally instead of physically) in the production sector are taken as population. Since it is impossible to reach the whole population in terms of time and budget, the employees in the automotive sector in the city of Bursa are taken as samples. A survey form, which consists of demographic questions and Whistleblowing Scale (Park, Blenkinsopp, Oktem \& Omurgonulsen, 2008) with 14 items, is prepared and delivered to the potential participants via email. 235 responses have been gathered and the data is analyzed via SPSS 22.0 package programme.

\section{Literature Review \\ 1.1. Whistleblowing}

How employees behave in the organization is closely related to their responsibility towards the organization and the value they add to the organization. However, the global business world brings some negative behaviors with it that affect the employees, that is, the ambition to be superior to competitors and to earn more money can cause some unethical behavior, either on purpose or not. The important thing is that negative events should be prevented when they are known by the employees or managers in the organization, and correct and necessary organizational environments should be created. In this direction, it is extremely important to report the existing situations to the relevant people in order to prevent unethical and immoral 
events in the organization. This situation is expressed as "whistleblowing" (Sarığlu Uğur \& Özdemir, 2019).

The term "whistleblowing" is a word used due to the whistling of the British police to warn a person who has a tendency to commit a crime (Başol \& Karatuna, 2015). Today, whistleblowing is defined as reporting an unethical or illegal event or situation to people who have the authority to solve this work. Whistleblowing can be formal whistleblowing or informal whistleblowing. When making an official/formal report, the whistleblower uses official channels. When informing the situation with an informal report, the whistleblower uses informal means such as informing someone he knows or trusts about this situation (Gökçe, 2014; Atılgan \& Koç, 2019).

\subsection{The Ways of Whistleblowing}

Whistleblowing can be performed in two ways, as internal and external. Internal whistleblowing is informing the authorities in the organization about wrong behavior or action (Miceli \& Near, 1994). External whistleblowing, on the other hand, is transferring the information outside the organization to the concerned parties (Chiasson, Johnson \& Byington, 1995; Jubb, 1999).

According to the observations, people who get involved in whistleblowing use internal channels first (Mesmer-Magnus \& Viswesvaran, 2005). This is because external whistleblowing can have more dangerous consequences than internal whistleblowing. However, internal whistleblowing is also not supported in the organizations. In this sense, employees who make internal whistleblowing can often be suppressed or ignored by the organization, especially by the managers. Therefore, being face with negative attitudes such as mobbing or dismissal, and turning the situation into a kind of cold war is thought to be worse than the failure of whistleblowing (MesmerMagnus \& Viswesvaran, 2005; Sayğan Tunçay \& Sayğan Yağız, 2020). On the other hand, internal whistleblowing has some advantages for both employers and employees such as giving the opportunity to deal with problems inside, without external whistleblowing, which can lead to scandals (Lewis, 2011).

External whistleblowing is defined as the reporting of illegal, improper or unethical actions within the organization to the authorities outside the organization. The authorities where information is transferred outside the organization are the state, the authorized institutions of the state, and the written or visual media. There are studies in the literature indicating that external whistleblowing should not be used without referring to internal whistleblowing, as it is more possible to damage the institutional identity of the organization or cause an important crisis with the spread and dissemination of information from these points. In this context, in cases where internal 
reporting is insufficient, external reporting should be applied (Eren \& Orhan, 2013; Kartal \& Sipahi, 2018).

\subsection{The Facts that Needs to be Whistleblowed"and the Facts that Affect Whistleblowing}

Whistleblowing can be defined as revealing information about organizational activities that harm employees, third parties, or threaten the public interest (Near \& Miceli, 1985) as mentioned above and unfortunately many unwanted, unpredictable, and unethical events and situations are encountered almost every day in organizations. However, the situations that require notice and thus whistleblowed can be listed as follows (Gerçek, 2005):

- Crimes such as fraud and theft

- In cases of discrimination such as race, religion, gender and nationality

- In violation of discipline and ethical rules, laws, moral values, state policy and legal regulations

- If there is a situation that threatens the safety or health of the society

Furthermore, The Government Accountability Project proposes four ways for whistleblowing (Berg, 2020):

- Reporting unethical situation or a violation of the law to the proper authorities

- Refusing to participate in unethical situation in the organization

- Testifying in a legal proceeding

- Leaking evidence of the unethical situation to the media

When whistleblowing is considered as a process, it is possible to say that this behavior includes four components. These can be listed as follows; whistleblower, whistleblowing action, the party to whom the notification was made, and the organization to which the notification was made (Miceli \& Near, 1985).

In short, members of the organization who engage in whistleblowing can prevent the production of unsafe products produced by organizations, take a step to correct unsuitable working conditions, or terminate fraudulent or wasteful practices. These people can also prevent harm to customers or employees, significant loss of sales, costly lawsuits that may be filed, or negative advertisements that may cause the organization to lose reputation (Dozier \& Miceli, 1985; Miceli \& Near, 1985; Sayğan Tunçay \& Sayğan Yağız, 2020).

Whistleblowers are affected by many factors such as personal factors, situational factors, and organizational factors in the reporting process. At this point, job satisfaction, organizational commitment, and attachment to moral values constitute personal factors; social sensitivity of individuals is among 
situational factors; and their belief in organizational culture is among organizational factors. Employees' decision and preference behaviors are shaped on the axis of these factors. They may decide to avoid doing anything in order to eliminate the mistakes they see, or they may first tell their friends and other employees that they see close to them or report the situation to the management within the organization. If they cannot, or they become unsuccessful, they report the situation outside the organization or they may have to leave the organization by losing their belief in solving this problem or by being subjected to psychological harassment, violence etc., due to their actions (Kartal \& Sipahi, 2018).

In addition, when the literature is scrutinized, it is observed that there are five main factors that are likely to affect whistleblowing activities (Hassink, Vries \& Bolle, 2007; Cemaloğlu \& Akyürek, 2017).

Cultural/Ethical Factors: It is seen that there may be a difference between the perceptions of people who have a certain culture towards whistleblowing, and at the same time, studies support this idea. For example, employees in Asian countries (such as Japan and China) tend to display more whistleblowing behavior than the employees in Western countries (such as America).

Retaliation and Revenge: If an employee believes that he/she will face negative consequences (such as a harsh punishment) when he/she reports an unethical behavior, he/she can stop whistleblowing.

Psychological Factors: The concept of organizational commitment, especially emotional commitment, are among these factors. An employee who is committed to his/her organization tends to whistleblow unethical practices in the organization as long as this creates an advantage to the organization.

Structural Factors: This factor includes organizations' policies about whistleblowing and legal regulations. As long as an organization acts with policies and practices that encourage whistleblowing, an employee tends to display more whistleblowing behavior. Otherwise, the employee is unlikely to be whistleblowing.

Type of Wrong/Unethical Practices: Whistleblowing varies, depending on the type of wrong/unethical practices.

\subsection{The Dangers for Whistleblowers and the Steps that Needs to be taken for an Efficient Whistleblowing Policy}

Whistleblowing behavior is an ethical behavior that is expected by everyone in terms of announcing the unethical and immoral behaviors and practices in an organization through internal or external ways, but there are also dangers especially for the whistleblower (Gerçek, 2005; Çiğdem, 2013):

- To draw attention to the whistleblower

- To give a weak track record/history 
- Forcing the whistleblower to be in silence via threats

- Applying mobbing to the whistleblower

- To lay the groundwork for failure

- To sue

- Destroying the whistleblowers career

In this sense, it can be easily understood that in all organizations there should be whistleblowing policies, as it is mentioned in the previous sections. An effective whistleblowing policy should be established within the organization in order to prevent the above mentioned dangers to the whistleblower. In order to create an effective whistleblowing policy within the organization, the steps that the organization should take are as follows (Uyar \& Yelgen, 2015):

- Determination of top management

- Education

- Contact

- Ombudsman Office

- Control and Supervision

- Rewarding

- Punishment

- Protection

- Written rules and codes

- Fair investigation process and public announcement of the result

- Providing correct information to the public

\subsection{Previous Researches}

Whistleblowing is a recently researched subject in both international and especially national context. In this section of the study, the previous researches are tried to be presented as examples.

As for international research, Rothwell and Boldwing (2006) stated that friendship and group climate have a negative effect on the realization of whistleblowing behavior in organizations; that is to say that, they concluded that this climate reduces whistleblowing.

Mesmer-Magnus and Visweswaran (2005) investigated the whistleblowing tendencies of employees in organizations. As a result of the research, it has been found that the older the age of the employees, and the more the job satisfaction, the less the whistleblowing behavior.

Lindblom (2007) examined the situation between whistleblowing and ethical dilemma in his research. As a result of the study, it was emphasized that it is an ethical behavior to report negativities/unethical behaviors to the authorities, especially in situations that concern the public. 
As for national studies, Sayğan Tuçay and Sayğan Yağız (2020), in the article they wrote, examined the summary parts of the articles in the literature and made "content analysis". According to their content analysis, the interest in "whistleblowing" in Turkey has increased in recent years and the articles mostly contain empirical research.

Baltac1 and Balc1 (2017) made interviews via semi-structured interview forms with 20 teachers, 12 administrators, and 7 inspectors. At the end of the research, the individual, organizational and social reasons for whistleblowing have been categorized. Among the individual reasons, the considerations of protecting and gaining interests were found. Among the organizational reasons, there have been found business ethics and the expectation of subsequent promotion. As for the social reasons, social benefits, social justice, and religious belief were found.

Özaslan and Ünal (2016), in their research, aimed to develop suggestions on measures that can be taken to understand the opportunities of teachers to exhibit disclosure behavior (whistleblowing) and to encourage teachers to reveal behavior by using the opinions of teachers, school administrators, and education supervisors. As a result of the research, it was found that the nature of the defect and how it was perceived was a determining factor in the teachers' courage to reveal their personal characteristics.

\section{Methodology}

Quantitative analysis is focused on objective measurements and statistical or mathematical analysis by collecting data through methods such as questionnaires. By collecting numerical data, quantitative analysis concentrates on generalizing this data to individual groups or explaining a particular phenomenon (Babbie, 2010).

The main problem and research hypothesis of this research focus on the "what" and "to what extent" of the relation between the demographic characteristics of the white collar employees in production sector organizations and their attitudes towards whistleblowing. In this context, the method of the study has been determined quantitatively. The sample of the study is taken as employees in the automotive sector in Bursa city. Questionnaire forms were used as a data collection method. The questionnaire forms prepared consist of demographic questions (gender, age, education, experience, department) and Whistleblowing Scale that is developed by Park et al. (2008) with 14 items, and delivered to the participants via email. 235 responses were gathered. The gathered data were analyzed in the SPSS 22.0 package programme. The reason why White collar employees are taken as a sample is the fact that they work mentally and thus, they pay more attention to the unethical situations within the organization. As for limitations, although there are a number of researches in both international and national literature, 
the research on sector based is not adequate in terms of making comparisons of the results.

\subsection{Hypothesis}

Ho: There is no statistically significant difference between the sociodemographical (gender, age, education, experience, department) characteristics of white collar employees in the production sector and their attitudes towards whistleblowing. $h_{0}: \mu 1>\mu 2$

H1: There is a statistically significant difference between the sociodemographic (gender, age, education, experience, department) characteristics of white collar employees in the production sector and their attitudes towards whistleblowing. $\mathrm{h}_{1}: \mu_{1}>\mu_{2}$

\subsection{Demographical Findings}

According to demographical findings, 85 (36,2\%) participants are women while $150(63,8 \%)$ participants are men. As for age groups, $30(12,8 \%)$ participants are in 18-29 age group, 82 (34,9\%) participants are in 30-39 age group, again $82(34,9 \%)$ participants are in 40-49 age group, 29 (12,3\%) participants are in 50-59 age group, and $12(5,1 \%)$ participants are in $60+$ age group. In terms of education, $8(3,4 \%)$ participants have high school degrees, $207(88,1 \%)$ participants have undergraduate degrees, and $20(8,5 \%)$ participants have post-graduate degrees.

\subsection{Reliability Findings}

The questionnaire form consists of two parts. The first part includes demographic questions and the second part includes the Whistleblowing Scale developed by Park et al. (2008). The original scale consists of 14 items and 2 dimensions named Internal Whistleblowing and External Whistleblowing. It was observed that the expressions of the scale in the current study were gathered under 2 dimensions as the original one. According to the reliability analysis of the scale, the Cronbach's alpha value is 0.780 .

Table 1. Cronbach's Alpha Value of the Scale

\begin{tabular}{lll} 
Scale & Cronbach's Alpha Value & Number of Items \\
\hline Whistleblowing Scale &, 780 & 14 \\
\hline
\end{tabular}

\subsection{Descriptive Statistics}

The descriptive statistics results of the Whistleblowing Scale show that the most important item according to the participants is the 3rd statement with a mean of 3.52, "I report the incident to the relevant employee's manager". Secondly, the idea of "I report the error to the relevant people in the institution" which is the 1st statement with an average of 3.29. At this point, 
it can be concluded that employees give great importance to reporting any incident to the superiors, which is internal whistleblowing. In the third place, there is the idea of "I report the incident in accordance with the existing procedures", which is the 12th statement with 3.24 average.

The least important thought of the participants was the 9th statement "I report the incident with a fake name" with an average of 1.54. From this, it can be concluded that the participants do not prefer keeping their identities as secret in the process of whistleblowing and thus, they prefer to be honest, which implies that employees support the well-being of their organizations and that is why they report the incidents to the superiors in order to take precautions. 
Table 2. Descriptive Statistics

\begin{tabular}{|c|c|c|c|c|c|c|c|c|}
\hline Items & & $\begin{array}{l}\text { Totally } \\
\text { Disagree }\end{array}$ & Disagree & Neutral & Agree & $\begin{array}{l}\text { Totally } \\
\text { Agree }\end{array}$ & $\mathbf{x}$ & $\begin{array}{l}\text { Standard } \\
\text { Deviation }\end{array}$ \\
\hline $\begin{array}{l}\text { 1-I report the error to the relevant people in } \\
\text { the institution. }\end{array}$ & $\begin{array}{l}\text { fi } \\
\text { Y.fi }\end{array}$ & $\begin{array}{l}14 \\
6,0\end{array}$ & $\begin{array}{l}59 \\
25,1\end{array}$ & $\begin{array}{l}62 \\
26,4\end{array}$ & $\begin{array}{l}44 \\
18,7\end{array}$ & $\begin{array}{l}56 \\
23,8 \\
\end{array}$ & 3,29 & 1,24506 \\
\hline $\begin{array}{l}\text { 2-I make sure that the senior management is } \\
\text { aware of the incident. }\end{array}$ & $\begin{array}{l}\text { fi } \\
\text { Y.fi }\end{array}$ & $\begin{array}{l}22 \\
9,4\end{array}$ & $\begin{array}{l}33 \\
14,0\end{array}$ & $\begin{array}{l}81 \\
34,5\end{array}$ & $\begin{array}{l}64 \\
27,2\end{array}$ & $\begin{array}{l}35 \\
14,9\end{array}$ & 3,24 & 1,15317 \\
\hline $\begin{array}{l}\text { 3-I report the incident to the relevant } \\
\text { employee's manager. }\end{array}$ & $\begin{array}{l}\text { fi } \\
\text { Y.fi }\end{array}$ & $\begin{array}{l}0 \\
0\end{array}$ & $\begin{array}{l}47 \\
20,0\end{array}$ & $\begin{array}{ll}83 \\
35,3\end{array}$ & $\begin{array}{l}40 \\
17,0\end{array}$ & $\begin{array}{l}65 \\
27,7 \\
\end{array}$ & 3,52 & 1,09899 \\
\hline $\begin{array}{l}\text { 4-I report the error to the relevant people } \\
\text { outside the institution. }\end{array}$ & $\begin{array}{l}\text { fi } \\
\text { Y.fi }\end{array}$ & $\begin{array}{l}100 \\
42,6\end{array}$ & $\begin{array}{l}34 \\
14,5 \\
\end{array}$ & $\begin{array}{l}77 \\
32,8 \\
\end{array}$ & $\begin{array}{l}4 \\
1,7\end{array}$ & $\begin{array}{l}20 \\
8,5\end{array}$ & 2,19 & 1,24788 \\
\hline $\begin{array}{l}\text { 5-I inform the authorities outside the } \\
\text { institution. }\end{array}$ & $\begin{array}{l}\text { fi } \\
\text { Y.fi }\end{array}$ & $\begin{array}{l}114 \\
48,5\end{array}$ & $\begin{array}{l}47 \\
20,0 \\
\end{array}$ & $\begin{array}{l}23 \\
9,8\end{array}$ & $\begin{array}{l}14 \\
6,0\end{array}$ & $\begin{array}{l}37 \\
15,7\end{array}$ & 2,20 & 1,48525 \\
\hline $\begin{array}{l}\text { 6-I let large masses learn about the event } \\
\text { outside the company. }\end{array}$ & $\begin{array}{l}\text { fi } \\
\text { Y.fi }\end{array}$ & $\begin{array}{l}136 \\
57,9\end{array}$ & $\begin{array}{l}48 \\
20,4 \\
\end{array}$ & $\begin{array}{l}41 \\
17,4 \\
\end{array}$ & $\begin{array}{l}0 \\
0\end{array}$ & $\begin{array}{l}10 \\
4,3\end{array}$ & 1,72 & 1,03160 \\
\hline $\begin{array}{l}\text { 7-I report the incident by stating my own } \\
\text { name. }\end{array}$ & $\begin{array}{l}\text { fi } \\
\text { Y.fi }\end{array}$ & $\begin{array}{l}91 \\
38,7\end{array}$ & $\begin{array}{l}8 \\
3,4 \\
\end{array}$ & $\begin{array}{ll}76 \\
32,3\end{array}$ & $\begin{array}{l}23 \\
9,8\end{array}$ & $\begin{array}{l}37 \\
15,7\end{array}$ & 2,60 & 1,47079 \\
\hline $\begin{array}{l}\text { 8-I report the incident by giving detailed } \\
\text { information about myself. }\end{array}$ & $\begin{array}{l}\text { fi } \\
\text { Y.fi }\end{array}$ & $\begin{array}{l}63 \\
26,8 \\
\end{array}$ & $\begin{array}{l}48 \\
20,4\end{array}$ & $\begin{array}{l}68 \\
28,9\end{array}$ & $\begin{array}{l}28 \\
11,9\end{array}$ & $\begin{array}{l}28 \\
11,9\end{array}$ & 2,61 & 1,31645 \\
\hline 9-I report the incident with a fake name. & $\begin{array}{l}\text { fi } \\
\text { Y.fi }\end{array}$ & $\begin{array}{l}188 \\
80,0\end{array}$ & $\begin{array}{l}0 \\
0\end{array}$ & $\begin{array}{l}23 \\
9,8\end{array}$ & $\begin{array}{l}14 \\
6,0\end{array}$ & $\begin{array}{l}10 \\
4,3\end{array}$ & $\mathbf{1 , 5 4}$ & 1,14780 \\
\hline $\begin{array}{l}\text { 10-I report the incident but avoid giving any } \\
\text { information about myself }\end{array}$ & $\begin{array}{l}\text { fi } \\
\text { Y.fi }\end{array}$ & $\begin{array}{l}118 \\
50,2\end{array}$ & $\begin{array}{l}35 \\
14,9\end{array}$ & $\begin{array}{l}51 \\
21,7\end{array}$ & $\begin{array}{l}19 \\
8,1\end{array}$ & $\begin{array}{l}12 \\
5,1\end{array}$ & 2,02 & 1,22787 \\
\hline 11-I use official ways to announce the event. & $\begin{array}{l}\text { fi } \\
\text { Y.fi }\end{array}$ & $\begin{array}{l}67 \\
28,5\end{array}$ & $\begin{array}{l}40 \\
17,0\end{array}$ & $\begin{array}{l}71 \\
30,2\end{array}$ & $\begin{array}{l}42 \\
17,9\end{array}$ & $\begin{array}{l}15 \\
6,4\end{array}$ & 2,56 & 1,25018 \\
\hline $\begin{array}{l}\text { 12-I report the incident in accordance with the } \\
\text { existing procedures. }\end{array}$ & $\begin{array}{l}\text { fi } \\
\text { Y.fi }\end{array}$ & $\begin{array}{l}23 \\
9,8\end{array}$ & $\begin{array}{l}49 \\
20,9 \\
\end{array}$ & $\begin{array}{l}52 \\
22,1 \\
\end{array}$ & $\begin{array}{l}69 \\
29,4 \\
\end{array}$ & $\begin{array}{l}42 \\
17,9\end{array}$ & 3,24 & 1,24668 \\
\hline $\begin{array}{l}\text { 13-I report the incident unofficially to my } \\
\text { colleagues whom I believe can solve the } \\
\text { problem and that I am close to. }\end{array}$ & $\begin{array}{l}\text { fi } \\
\text { Y.fi }\end{array}$ & $\begin{array}{l}104 \\
44,3\end{array}$ & $\begin{array}{l}42 \\
17,9\end{array}$ & $\begin{array}{l}75 \\
31,9\end{array}$ & $\begin{array}{l}14 \\
6,0\end{array}$ & $\begin{array}{l}0 \\
0\end{array}$ & 1,99 & 1,00213 \\
\hline $\begin{array}{l}\text { 14-I convey the error informally to a person } \\
\text { who I trust and who has the authority to solve } \\
\text { the problem. }\end{array}$ & $\begin{array}{l}\text { fi } \\
\text { Y.fi }\end{array}$ & $\begin{array}{l}131 \\
55,7\end{array}$ & $\begin{array}{l}6 \\
2,6\end{array}$ & $\begin{array}{l}41 \\
17,4\end{array}$ & $\begin{array}{l}39 \\
16,6\end{array}$ & $\begin{array}{l}18 \\
7,7\end{array}$ & 2,17 & 1,43595 \\
\hline
\end{tabular}




\subsection{Factor Analysis}

According to the factor analysis (Table 3), it was seen that the Whistleblowing Scale was collected under two dimensions. These dimensions have been named as External and Internal Whistleblowing. While the External dimension explains the Whistleblowing Scale with a percentage of 42,689, the dimension of Internal whistleblowing explains with a percentage of 30,270. The cumulative percentage of both dimensions was found to be 72,959 .

Table 3. Explained Total Variance

\begin{tabular}{lllllll}
\hline Component & \multicolumn{3}{c}{ Calculated Sum of Squares } & \multicolumn{3}{c}{ Rotated Sum of Squares } \\
\cline { 2 - 7 } & Total & $\%$ & Cumulative\% & Total & \% Variance & Cumulative\% \\
& \multicolumn{3}{c}{ Variance } & & & \\
\hline 1 & 3,949 & 49,363 & 49,363 & 3,415 & 42,689 & 42,689 \\
2 & 1,888 & 23,596 & 72,959 & 2,422 & 30,270 & 72,959
\end{tabular}

\subsection{Comparative Statistics}

The Mann-Whitney U and Kruskal-Wallis tests were used to analyze whether there was a statistical difference in the answers given by the participants according to their socio-demographic findings regarding the dimensions obtained as a result of the factor analysis (Table 4). It was observed that there was a statistically significant difference in both sociodemographic characteristics (gender, age, education, experience, department) and both dimensions (internal/external) ( $\mathrm{p}<0.05$ ) except from internal whistleblowing for experience characteristic. Hence, the H1 hypothesis, there is a statistically significant difference between the socio-demographic (gender, age, marital status, education, income) characteristics of white collar employees in the production sector and their attitudes towards whistleblowing. h1: $\mu 1>\mu 2$, was accepted.

Table 4. Comparative Statistics

\begin{tabular}{|l|l|l|l|l|}
\hline Variable & Dimension & Test & Statistics & $\mathbf{P}$ \\
\hline Gender & $\begin{array}{l}\text { External } \\
\text { Internal }\end{array}$ & $\begin{array}{l}\text { Mann-Whitney } \\
\text { U }\end{array}$ & 4138,500 & $\mathbf{0 0 0}$ \\
& & 3712,000 & $\mathbf{0 0 0}$ \\
\hline Age & External & Mann-Whitney & 41,573 & $\mathbf{, 0 0 0}$ \\
& Internal & U & 60,551 & $\mathbf{0 0 0}$ \\
\hline Education & External & Kruskal-Wallis & 41,070 & $\mathbf{, 0 0 0}$ \\
& Internal & & 29,636 & $\mathbf{, 0 0 0}$ \\
\hline Experience & External & Kruskal-Wallis & 24,699 & $\mathbf{, 0 0 0}$ \\
& Internal & & 6,193 & $\mathbf{1 0 3}$ \\
\hline $\begin{array}{l}\text { Department in } \\
\text { the Organization }\end{array}$ & External & Knternal & & $\mathbf{0 0 0}$ \\
\hline
\end{tabular}




\section{Conclusion}

Despite the increasing importance given to ethics in the business world today, unethical behaviors and practices are frequently encountered in recent years. It is possible to encounter whistleblowing examples in the context of interfering with such behaviors and applications (Kartal \& Sipahi, 2018).

According to the findings of the current study on whistleblowing attitudes of the white collar employees, there is a statistically significant difference in both socio-demographic characteristics (gender, age, education, experience, department) and both dimensions (internal/external) $(\mathrm{p}<0.05)$ except from internal whistleblowing for experience characteristic. In this sense, it can be concluded that the employees use whistleblowing both internally and externally. This result may imply many causes such as employees' desire for the well-being of their organizations. They may report every incident to their superiors in order to take precautions as mentioned before. In addition, for more important incidents, they may prefer to report the incidents to the external parties in order to prevent their organizations from bringing harm to the society. In short, it can be concluded that the employees' desire is protecting both their organizations and the society. It should also be added that during the COVID-19 process, most of the organizations have been affected. In this sense, it can be concluded that the participants try to protect their organizations from facing more harm because of unethical situations within the organization. Although there are a number of researches in both international and national literature, the research on sector based is not adequate in terms of making comparisons of the results. In addition, the fact that the pandemic conditions are almost new, and there is almost no research in the literature in terms of whistleblowing attitudes of the employees under the pandemic conditions.

For further studies, these kinds of research would shed light to the academicians because of the fact that there is a lack of research in the area of whistleblowing, which is in fact a really important area in terms of organizations. Furthermore, professionals and managers can get help from the researchers and analyze the whistleblowing activities in their organizations. It should not be forgotten that whistleblowing activity can be harmful for the organizations if it is carried by employees who have bad intentions.

\section{References:}

1. Atılgan, A. \& Koç, E. (2019). Whistleblowing: Türkiye'den iki örnek olay. Selçuk Üniversitesi Sosyal Bilimler Enstitüsü Dergisi (41). 380389.

2. Baltac1, A. \& Balc1, A. (2017). Reasons for whistleblowing: A qualitative Study. Eğitim Bilimleri Araştırmaları Dergisi - Journal of Educational Sciences Research, 7(1). 37-51. 
3. Başol, O. \& Karatuna, I. (2015). Örgütlerde olumsuz durumların ifşa edilmesi ve örgütsel iletişim ilişkisi. Marmara Üniversitesi İ.I.B. Dergisi, 37 (2). 153-170.

4. Becker, E. (2014). Calling foul: Deficiencies in approaches to environmental whistleblowers and suggested reforms. Washington and Lee Journal of Energy, Climate, and the Environment, 6(1), 65-97.

5. Berg, K. T. (2020). The ethics of whistleblowing. Journal of Media Ethics, 35(1).60-64.

6. Cemaloğlu, N. \& Akyürek, M. (2017). Örgütlerde whistleblowing (Bilgi uçurma). Turkish Journal of Educational Studies, 4(3).

7. Chiasson, M., Johnson, G. H. \& Byington, J. R. (1995). Blowing the whistle: Accountants in industry. The CPA Journal, 65(2), 24-27.

8. Cross, F. B. \& Tiller, E. H. (1998). Judicial partisanship and obedience to legal doctrine: Whistleblowing on the federal courts of appeals. Yale Law Journal, 107(7), 2155-2176.

9. Çiğdem, S. (2013). Büro yönetiminde whistleblowing ve etik ilişkisi. Süleyman Demirel Üniversitesi Sosyal Bilimler Enstitüsü Dergisi, 1, 93-109.

10. Delk, K. L. (2013). Whistleblowing-Is it really worth the consequences? Workplace Health \& Safety, 61(2), 61-64.

11. Dozier, J. B. \& Miceli, M. P. (1985). Potential predictors of whistleblowing: A prosocial behavior perspective. Academy of Management Review, 10(4), 823-836.

12. Eren, V. \& Orhan, U. (2013). Kurumsal sosyal sorumluluğun çalışanların kötü yönetimi ifşa düzeylerine etkisi üzerine bir araştırma. International Journal of Social Science. 6(2), 455-468.

13. Gerçek, H. (2005). Mühendislikte etik sorunların ele verilmesi. Madencilik, 44(4), 29-38.

14. Gökçe, A. T. (2014). Okullarda bilgi uçurma: İş doyumu ve örgütsel bağl1lık ilişkisi. Dicle Üniversitesi Ziya Gökalp Ĕ̈itim Fakültesi Dergisi. 22. 261-282.

15. Hassink, H., Vries, M. \& Bollen, L. (2007). A content analysis of whistleblowing policies of leading eoropean companies. Journal of Business Ethics, 75, 25-44.

16. Jubb, P. B. (1999). Whistleblowing: A restrictive definition and interpretation. Journal of Business Ethics, 21(1), 77-94.

17. Kartal, Y. \& Sipahi, H. (2018). Whistleblowing ile mobbing ilişkisi: Kavramsal bir bakış ve çözüm önerileri. International Journal of Management and Administration. 2(2).

18. Lewis, D. (2011). Whistleblowing in a changing legal climate: Is it time to revisit our approach to trust and loyalty at the workplace? Business Ethics: A European Review, 20(1), 71-87. 
19. Lindblom, L. (2007). Dissolving the moral dilemma of whistleblowing. Journal of Business Ethics, 76, 413-426.

20. Mesmer-Magnus, J. R. \& Viswesvaran, C. (2005). Whistleblowing in organizations: An examination of correlates of whistleblowing intentions, actions and retaliation. Journal of Business Ethics, 62, 277297.

21. Miceli, M. P. \& Near, J. P. (1985). Characteristics of organizational climate and perceived wrongdoing associated with whistleblowing decisions. Personnel Psychology, 38, 525-544.

22. Miceli, M. P. \& Near, J. P. (1994). Whistle-blowing: reaping the benefits. Academy of Management Executives, 8(3), 65-72.

23. Near, J. P. \& Miceli, M. P. (1985). Organizational dissidence: The case of whistle-blowing. Journal of Business Ethics, 4(Pre-1986), 1-16.

24. Özaslan, G. \& Ünal, G. (2016). Öğretmenlerde açığa çıkarma davranış1: Mevcut durum ve öneriler. Kuram ve Uygulamada Ĕgitim Yönetimi Dergisi, 22 (3), 321-350.

25. Park, H., Blenkinsopp, J., Öktem, M. K. \& Ömürgönülşen, U. (2008). Cultural orientation and attitudes toward different forms of whistleblowing: A comparison of South Korea, Turkey, and the U.K. Journal of Business Ethics, 82(4), 929-939.

26. Poitras, L. (2014). Citizenfour. Praxis Films. Film. https://citizenfourfilm.com.

27. Rothwell, G. R. \& Baldwin, N. J. (2006). Ethical climate theory, whistleblowing, and the code of silence in police agencies in the state of Georgia. Journal of Business Ethics, 70, 341-361.

28. Sayğan Tunçay, S. \& Sayğan Yağız, F. N. (2020). Türkiye'deki "bilgi uçurma (whistleblowing)" makalelerinin bibliyometrik profili, BMIJ, 8(4). 266-295.

29. Sarığlu Uğur, S. \& Özdemir, L. (2019). Onlarda "whistleblowing" Peki ya bizde? Kavramsal bir araştırma ve bir öneri. Akademik Sosyal Araştırmalar Dergisi, Y1l: 7(89). 71-79.

30. Uyar, S. \& Yelgen, E. (2015). Bilgi ifşası (whistleblowing) ve denetim. Yönetim ve Ekonomi Araştırmaları Dergisi, 13(1), 85-106. 